\section{2 ๖)}

\section{Adolescence, its Social Psychology}

With an Introduction to Recent Findings from the Fields of Anthropology, Physiology, Medicine, Psychometries and Sociometry. By Dr. C. M. Fleming. (International Library of Sociology and Social Reconstruction.) Pp. vii +262. (London : Routledge and Kegan Paul, Ltd., 1948.) 16s. net.

$\mathrm{D}^{\mathrm{n}}$

R. CHARJORTTE FLEMING'S work on the social phychology of adolescence is one which has not foceived the prominence it deserves. Not opły liods the author write with a pen which unefringly traces the right word, but her beliefs are also substantiated by a wide acquaintance with the relevant literature which is freely referred to in this book. The way these references are used suggests that Dr. Fleming collects and uses her facts with scientific detachment, and that the views she has formed are likely to be of considerable significance. It is not surprising, therefore, to learn that the book differs from many previous works on adolescence, with their emphasis on characteristics which young people are supposed to show as they grow up.

Dr. Fleming rebels against the treatment of adolescents in terms of the average, and shows that the effectiveness of education depends upon the study of children always as individuals. The work of theorists like Rousseau and early observers like Stanley Hall and Freud are shown to be inadequate to the understanding of youth and, instead of the storm and stress, conflict and rebellion, moodiness and apathy which have been built up as the legendary experience of all adolescents, Dr. Fleming redirects attention to the continuity of human growth, the gradualness and irregularity of human development and the extent of human educability and adaptability. Although many may feel that Dr. Fleming has gone too far in upsetting accepted ideas on adolescence, there will be many more who will welcome this scientific treatment of an important period in the maturation of human beings.

$$
3 / 6
$$

T. H. H.

\section{Children of the People}

The Navaho Individual and his Development. By Dr. Dorothea Leighton and Dr. Clyde Kluckhohn. Pp. xvi $+277+15$ platps. (Cambridge, Mass: Harvard University Presf $f$ London: Oxford University Press, 1948.) 25s (poct.

TTHE au 9 have been working among the Nava 10 or several years and have already pub. lished "the" Navaho", an account of their life and envifonhtent. The present work deals with the indicqual, and particularly with the child and his evirdnment.

The Navaho, like other Indian peoples, are feeling the pressure of white civilization to an increasing extent, and it is the duty of the employees of the Office of Indian Affairs to help them to accommodate themselves. The Indian Education Research Project, for which the authors are working, is trying to equip them with the requisite knowledge. It will not be necessary to tell those who have read their previous book that Drs. Leighton and Kluckhohn bring the greatest possible sympathy and understanding to the task.

A good deal of space is taken up with the results of intelligence tests, and they are compared with the performances of white children; the value of this is difficult to appraise, but it appears that some at least of these tests do not give natural intelligence a fair chance in comparison with school education. The book, like its predecessor, is well produced and illustrated, and is, in the main, easily readable.

$$
\text { G. H. S. BuSHNELL }
$$

Pioneers of Fertility

By Crichton Porteous and Michael Ayrton. Pp. 126. (London: Fertilizer Journal, Ltd., 1948.) $10 s$.

IN this ${ }^{\text {ery }}$ dable little book the author sets out the of hievement of twenty-two agricultural pionem 1 ho left their mark on English farming fropes the middle of the sixteenth to the end of the ninfeteenth centuries. All are English except one-the great German chemist, Justus von Liebig, whose stimulating book published in 1840 cleared the way for the modern period. Few of these personalities were farmers in the ordinary sense of the word, for farmers had little time or inclination for writing, still less for exact experimentation. Some were land. lords like 'Turnip' Townshend, the Dukes of Bedford and Coke of Norfolk. Arthur Young was a writer. Some, such as John Mechi and Knight of Exmoor, drew their money from industry and put it into the land. Sir Humphry Davy, Lawes and Gilbert were men of science. All had their eyes fixed on what they rightly regarded as a matter of supreme importance - to raise the output of the land and to maintain it in its improved condition. The book is written in a lively style and has a number of imaginative drawings by Michael Ayrton. It forms a useful introduction for general readers, while students will be encouraged to read further upon the same lines.

British Birds in their Haunts

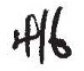

By the late Rev. C. A. Johns. Edited and revised by W. B. Alexander. Twenty-fifth edition. Pp. xv + 286 + 69 plates. (London: Routledge and Kegan Paul, Ltd., 1948.) 16s. net.

/ODERN books about British birds are legion, 1 most of them excellent, yet the most scientific

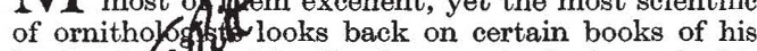
boyhood fit a sigh of loving regret. Such, no doubt, wat the feeling of Mr. W. B. Alexander when he pid kd up Johns's "British Birds in their Haunts"; indeed, he says in the preface to this latest edition that one of his most cherished possessions as a boy was a copy of "Johns" received as a Christmas present when he was seven years old.

Johns's "British Birds" not only reigned long as a classic of its subject, but also started many a young person on the path of ornithological research. Probably more people to-day owe their love of birds to its author than to any other writer. It was, and is, a good book ; but times change, scientific classification has been altered and scientific names, too; in short, Johns needed bringing up to date. No one was better qualified to undertake the task of modernizing the book than Mr. Alexander. It is obvious he approached it lovingly and he has done it admirably.

We have before us the old "Johns" but thoroughly revised. For example, the editor has rearranged the sequence of orders and families in accordance with modern practice; but within each family the species have been left as Johns arranged them. The status and distribution of many birds has changed since Johns's day and in some cases is better known, so where changed circumstances demand it additional information is given. In short, this revised edition gives us an up-to date and reliable guide to "British Birds in their Haunts".

Frances Pitt 